\title{
Design Of The Organizational Structure And Coordination Of An Observatory Based On Collective Intelligence
}

Diseño de la estructura organizacional y de coordinación de un observatorio basado en inteligencia colectiva

\author{
Desenho da estrutura organizacional e coordenação de um \\ observatório baseado em inteligência coletiva
}

\section{Luz-Esperanza-Bohorquez-Arévalo ${ }^{1}$ Nelson-Stiven-Castillo-Rodriguez ${ }^{2}$ Mónica-Sofía-Farfán-González ${ }^{3}$}

Received: September 20 ${ }^{\text {th }}, 2019$

Accepted: November $27^{\text {th }}, 2019$

Available: January $31^{\text {th }}, 2020$

How to cite this article:

L.E. Bohorquez-Arévalo, N. S. Castillo-Rodriguez, M.S. Farfán-González, "Design of The Organizational Structure and Coordination of an Observatory Based on Collective Intelligence," Revista Ingeniería Solidaria, vol. 16, no. 1, 2020.

doi: https://doi.org/10.16925/2357-6014.2020.01.10

Artículo de investigación. https://doi.org/10.16925/2357-6014.2020.01.10

1 Faculty of Engineering. Universidad Distrital Francisco José de Caldas, Bogotá, Colombia ORCID: https://orcid.org/0000-0001-8401-3471

Email: lebohorqueza@udistrital.edu.co

2 Faculty of Engineering. Universidad Distrital Francisco José de Caldas, Bogotá, Colombia ORCID: https://orcid.org/0000-0001-5816-6191

E-mail: nscastillor@correo.udistrital.edu.co

3 Faculty of Engineering. Universidad Distrital Francisco José de Caldas, Bogotá, Colombia ORCID: https://orcid.org/0000-0001-6278-6852

E-mail: msfarfang@correo.udistrital.edu.co 


\begin{abstract}
Introduction: This article is the product of research developed within the framework of the Emple-ap Project, throughout 2019 at the School of Industrial Engineering, Universidad Distrital Francisco Jose de Caldas.
\end{abstract}

Problem: Limitations in the use of traditional hierarchical structures for the management of organizations based on control hierarchies, due to their difficulty in operating efficiently in human social systems (HSS).

Objective: To generate a general proposal to understand the structure and organizational management for the observatory of employability of the Pacific Alliance (PA) supported by collective intelligence (CI) and high reliability organization (HRO).

Methodology: The methodology for the development of the proposal is supported on grounded theory, in which the design emerges from the statements made in previous research.

Results: Based on the results of the review, it presents a proposal for organizational structure for the observatory, emphasizing the alternatives to divide and coordinate the work and the important characteristics of the structure to facilitate the exploitation of available resources.

Conclusion: The $\mathrm{Cl}$ and reliable organizations, are a different and decentralized way of management in organizations that allow you to create more flexible and robust systems. This study creates a general outline of the characteristics and main preconditions that must have a system based on $\mathrm{Cl}$.

Originality: The main contribution of this research lies in the design of an organizational structure, different from the traditional hierarchical structure, supported by $\mathrm{Cl}$ for the management of an entire organization.

Limitations: Currently, there are no great advances with respect to organizational structures or alternatives to the traditional hierarchies of control, despite limitations in information processing and the impact that has on performance.

Keywords: Observatory, Collective Intelligence, Reliable Organizations, Knowledge Manager.

\title{
Resumen
}

Introducción: El presente artículo es producto de una investigación desarrollada en el marco del proyecto Emple-ap, a lo largo del 2019 en la escuela de ingeniería Industrial, Universidad Distrital Francisco José de Caldas.

Problema: Limitaciones en el uso de las estructuras jerárquicas tradicionales para la gestión de las organizaciones basadas en jerarquías de control, por su dificultad para operar eficientemente en Sistemas Sociales Humanos (SSH).

Objetivo: Generar una propuesta general que comprenda la estructura y gestión organizacional para el observatorio de empleabilidad de la alianza del pacifico (AP) soportado en inteligencia colectiva (IC) y en organizaciones de alta confiabilidad.

Metodología: La metodología para el desarrollo de la propuesta se soporta en teoría fundamentada, en el que el diseño emerge a partir de los planteamientos realizados en investigaciones previas.

Resultados: A partir de los resultados de la revisión, se presenta la propuesta de estructura organizacional para el observatorio, enfatizando las alternativas para dividir y coordinar el trabajo, y las características importantes de la estructura para facilitar el aprovechamiento de los recursos disponibles en el medio.

Conclusiones: La IC y las organizaciones fiables, son una forma diferente y descentralizada de gestión en las organizaciones que permite crear sistemas más flexibles y robustos, este estudio crea un esquema general de las características y precondiciones principales que debe tener un sistema basado en IC. 
Originalidad: El principal aporte de la presente investigación radica en el diseño de una estructura organizacional diferente a la estructura jerárquica tradicional, soportada en IC para la gestión de toda una organización.

Limitaciones: Actualmente no existen grandes avances respecto a estructuras organizacionales alternativas a las tradicionales jerarquías de control a pesar de sus limitaciones en el procesamiento de información y en la incidencia que tendrían en su desempeño.

Palabras clave: Observatorio, Inteligencia Colectiva, Organizaciones Fiables, Gestor de conocimiento.

\section{Resumo}

Introdução: este artigo é o produto de uma pesquisa realizada no âmbito do projeto Emplo-ap, ao longo de 2019 na Escola de Engenharia Industrial da Universidade Distrital Francisco José de Caldas.

Problema: Limitações no uso de estruturas hierárquicas tradicionais para o gerenciamento de organizações baseadas em hierarquias de controle, devido à dificuldade de operar eficientemente nos Sistemas Sociais Humanos (SSH).

Objetivo: Gerar uma proposta geral que inclua a estrutura organizacional e o gerenciamento do observatório da empregabilidade da Aliança do Pacífico (PA) apoiado em inteligência coletiva (CI) e em organizações de alta confiabilidade.

Metodologia: A metodologia para o desenvolvimento da proposta é apoiada pela teoria fundamentada, na qual o design emerge das abordagens feitas em pesquisas anteriores.

Resultados: Com base nos resultados da revisão, é apresentada a estrutura organizacional proposta para o observatório, enfatizando as alternativas para dividir e coordenar o trabalho e as características importantes da estrutura para facilitar o uso dos recursos disponíveis no ambiente .

Conclusões: O IC e as organizações confiáveis são uma forma diferente e descentralizada de gerenciamento nas organizações que permite criar sistemas mais flexíveis e robustos. Este estudo cria um esquema geral das principais características e pré-condições que um sistema baseado em IC deve ter.

Originalidade: A principal contribuição desta pesquisa está no desenho de uma estrutura organizacional diferente da estrutura hierárquica tradicional, apoiada pelo $\mathrm{Cl}$ para o gerenciamento de uma organização inteira.

Limitações: Atualmente, não há grandes avanços em relação às estruturas organizacionais alternativas às hierarquias de controle tradicionais, apesar de suas limitações no processamento de informações e do impacto que elas teriam no desempenho.

Palavras-chave: Observatório, Inteligência Coletiva, Organizações Confiáveis, Gerente de Conhecimento.

\section{INTRODUCTION}

Emple-ap is an international cooperation project that has as one of its objectives, the creation of an observatory of employability and labor insertion for the countries of the Pacific Alliance (PA). It arose thanks to the Erasmus+ program of the European Union, and nowadays is composed of 10 higher education institutions of the PA, and 4 of the European Union [1]. The relevance of this work lies in the fact that it addresses one of the central problems in the human organization design; the configuration of the organizational structure is understood as the division of labor and coordination 
mechanism that shows the formal pattern of interactions that allow for problem-solving and decision-making.

Nowadays, there are many investigations that show, in part, the relevance of organizational structure and coordination mechanisms in the success and sustainability of organizations [2]. They also show the importance of flexible structure design which facilitates the adaptable exchange of information, and that this exceeds the restrictions of hierarchical structures and coordination mechanisms based on supervision and standardization [3]. However, there is little research in terms of the impact of the structure in the design of observatories, and in particular on intensive observatories and generators of knowledge [4].

Traditionally the organizational structure has been defined as a formal pattern of relationships and activities between parts of an organization. They show who depends on who and how to divide such activities [5] [6] [7]. Daft points out that "the structure also includes the design of systems to ensure communication, coordination and effective integration of efforts between departments." [8, p.90]. Franklin, Benjamin, \& Fincowsky highlighted that the organizations "require a framework of action to operate. This framework is the organizational structure, which is nothing but an orderly and systematic division of their units of work in response to their creation purpose" [9, p.65].

The coordination by its side has been understood as the integration of functional units of an organization in pursuit of their goals, where the crucial tool is the synchronization of efforts [10] [11] [12]. Malone \& Crowston [13] define the theory of coordination as the set of principles on how the actors can work together in harmony. Castillo, Gómez, \& Bohorquez [14] warn of the importance of coordination mechanisms set up in conjunction with the organizational structure.

Mintzberg asserts that: "All organized human activity raises two fundamental requirements and opposites: the division of labor when performing many tasks and the coordination of these tasks to carry out the activity" [2, p.116]. He also posits some coordination mechanisms that describe fundamental ways in which organizations coordinate their work: mutual adaptation, direct supervision, standardization of processes, standardization of results, skills standardization and standardization of rules, raised from most to least important, depending on the complexity of the work [2].

Nowadays, the dominant structure in the organizational context has been the hierarchy of control, which is dominated by mechanisms of coordination based on supervision and standardization, however, in complex environments, hierarchies manifest great precariousness in the processing of information, due to limited connections between nodes and vertical and horizontal flows. It generates excessive dependence 
and fragility, since it limits the information that members can have access to along with slowness in decision-making processes, and a high probability of failure; a product of the huge manipulation of information between levels of hierarchy [3].

The growing complexity of the environment has led to the traditional paradigms being insufficient at the time of giving a timely response [15]. The rigidity of the hierarchies limits the interaction and diversity of individuals, tending to a static balance and decreasing the creativity and ability to adapt to the environment. On the other hand, the complex networks can overcome the limitations of the hierarchies of classical control, being characterized by high robustness and information processing capacity [3], to the approach of a proposal that is capable of behaving similarly; the $\mathrm{Cl}$ as an alternative of coordination in organizations.

The $\mathrm{Cl}$ facilitates a quick information transfer, with flows that may occur in any direction, the product of a high level of interaction, distributing the load of information as evenly as possible, thus avoiding delays and overloads in the network [16]. Angulo [17] highlights the observatories as catalysts of $\mathrm{Cl}$ in facilitating the interaction of multiple agents to generate value, but also acknowledges difficulty in the transition of rigid hierarchies to $\mathrm{Cl}$, due to feelings of power loss and questioning of the legitimacy of the organization. Beyond this, there is no evidence of a clear organizational structure or observatory that supports its management in $\mathrm{Cl}$.

Regarding the labor division, the $\mathrm{Cl}$ alone is insufficient. Its implementation is given to specific purposes and not to the management of an entire organization. Malone, Friedrich-heinrich \& Dellarocas indicate the need for a "Gene Hierarchy" [18, p.26] for management when conditions are not met in order to work with crowds. Angulo [17] argues the difficulty of giving precise functions and responsible actors in an observatory. Highly reliable or reliable organizations, could be constituted as an appropriate framework for the division of labor [9] by establishing clearly defined roles that can be assumed by any qualified member [19], providing sufficient flexibility to allow the emergence of $\mathrm{Cl}$.

In this sense, the contribution of this research is to propose an outline of organizational structure and coordination in order to define how to operate the observatory of employability and labor insertion of the PA, to take advantage of the knowledge available in the environment, be agile in decision-making despite being geographically distributed, facilitate their adaptation and comprehensively overcome the limitations of traditional hierarchical structure. 


\section{MATERIALS AND METHODS}

The present investigation is supported on grounded theory as a methodology for the knowledge of a social phenomenon. Grounded theory emerges as a qualitative method of research in social groups and organizations, is based on the study of data obtained directly from the field of study, for the construction of concepts, hypotheses, theories or the deepening of a topic in question [20]. It is developed in fields such as management, information systems and business creation. It can provide a variety of details and processes for the creation of an organizational system based on $\mathrm{Cl}$.

In [21] it is pointed out that certain actions must be performed to conduct a systematic design of grounded theory. The main phases of this investigation are presented in Figure 1.

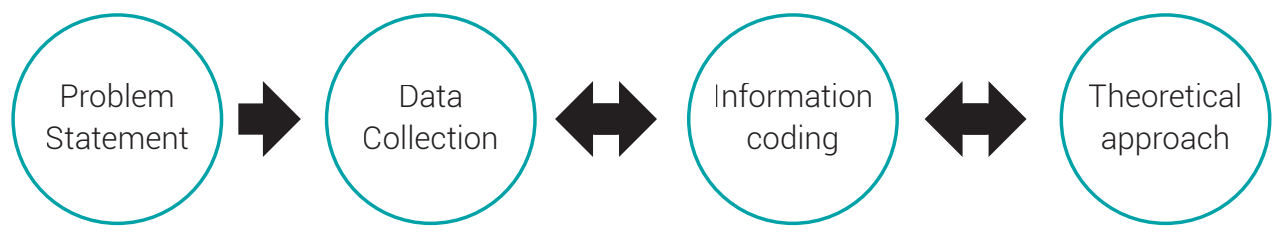

Figure 1. Phases of the investigation

Source: own work

Table 1 presents the stages of this research. The resources used were based both on searches of specialized databases and books, for the collection and classification of information and observation of its impact in addition to joint participation in groups such as Complex UD, interviews and consultations within the framework of the Emple-ap project for contextualization and development.

Table 1. Stages of the methodology

\begin{tabular}{lcl}
\hline \multicolumn{1}{c}{ Phase } & Stage & \multicolumn{1}{c}{ Definition } \\
\hline Problem Statement & So & $\begin{array}{l}\text { Identification of the particular conditions of the PA employability and labor } \\
\text { insertion observatory and the limitations of traditional organizational struc- } \\
\text { tures. }\end{array}$ \\
\hline Data collection & S1 & $\begin{array}{l}\text { Literature review on Cl. Literature review of the Cl in HSS (With emphasis on } \\
\text { how coordination occurs). }\end{array}$ \\
\cline { 2 - 4 } $\begin{array}{l}\text { Information coding: } \\
\text { open, axial and } \\
\text { selective }\end{array}$ & S3 & $\begin{array}{l}\text { Collection of information about HRO and observatories (With emphasis on } \\
\text { how the division of labor occurs). }\end{array}$ \\
\cline { 2 - 4 } & S4 & $\begin{array}{l}\text { Comparison of the characteristics of the Cl models in HSS identified in S3, to } \\
\text { recognize differences and similarities. }\end{array}$ \\
\hline
\end{tabular}


(viene)

\begin{tabular}{lcl}
\hline Phase & Stage & \multicolumn{1}{c}{ Definition } \\
\hline $\begin{array}{l}\text { Theoretical } \\
\text { approach }\end{array}$ & S5 & $\begin{array}{l}\text { Structuring Cl levels: common approaches and characteristics that facilitate } \\
\text { the understanding and use of Cl in HSS. }\end{array}$ \\
\cline { 2 - 3 } & S6 & $\begin{array}{l}\text { Structuring roles in the context of the observatory and the basic means } \\
\text { through which the actors connect and coordinate. }\end{array}$ \\
\hline
\end{tabular}

Source: own work

The following describes how each of these stages were performed:

SO: The starting point of this research is to recognize the disadvantages and limitations of the control hierarchies, and how inconvenient a traditional approach to the employability observatory would be. This is also projected as a knowledge-intensive organization, distributed geographically and made up of agents representing organizations; also knowledge intensive.

S1: Focuses on the search for alternative coordination mechanisms to the traditional ones. In the first instance, emphasis is placed on $\mathrm{Cl}$ and its application in HSS, due to previous knowledge of the high levels of coordination that characterize these systems. This stage is then based on extensive searches in different databases. Table 2 presents some search criteria and relevant authors.

Table 2. Classification of the review

\begin{tabular}{|c|c|c|c|}
\hline Keywords & Databases & Journals & $\begin{array}{c}\text { Author and year of } \\
\text { publication }\end{array}$ \\
\hline \multirow{6}{*}{$\begin{array}{l}\text { Collective Intelli- } \\
\text { gence }\end{array}$} & Access Engineering & \multirow{2}{*}{$\begin{array}{l}\text { Centro Nacional de Infor- } \\
\text { mación de Ciencias Médicas } \\
\text { (INFOMED). }\end{array}$} & P. Lévy (1997) \\
\hline & IEEE Xplore, Science- & & T. Atlee y G. Pór (2000) \\
\hline & & \multirow{3}{*}{$\begin{array}{l}\text { Dissertation Abstracts Interna- } \\
\text { tional Section A: Humanities } \\
\text { and Social Sciences. }\end{array}$} & K. McHugh (2016) \\
\hline & Scopus & & T. Malone (2010) \\
\hline & Jstor & & Bonabeau, Eric (2009) \\
\hline & & $\begin{array}{l}\text { MIT Sloan Management } \\
\text { Review. }\end{array}$ & G. Pór (1995) \\
\hline \multirow{9}{*}{$\begin{array}{l}\text { Using Collective } \\
\text { Intelligence in... }\end{array}$} & \multirow{3}{*}{$\begin{array}{l}\text { Access Engineering } \\
\text { IEEE Xplore, Science- } \\
\text { Direct }\end{array}$} & Royal Society Open Science. & \multirow{2}{*}{$\begin{array}{l}\text { A. Camacho, M. Merayo, M. Núñez } \\
(2017) \text {. }\end{array}$} \\
\hline & & Journal of Intelligent and & \\
\hline & & Fuzzy Systems. & \multirow{2}{*}{$\begin{array}{l}\text { G. Hernández, A. Rodríguez, G. } \\
\text { Alor, J. M. Gómez, M. A. Mayer, } \\
\text { and R. Posada (2012). }\end{array}$} \\
\hline & Scopus & Journal of Medical Systems. & \\
\hline & \multirow[t]{5}{*}{ Jstor } & Journal of Business Research. & \multirow{2}{*}{$\begin{array}{l}\text { M. Mačiulienè, A. Skaržauskienè } \\
\text { (2016). }\end{array}$} \\
\hline & & International Conference on & \\
\hline & & \multirow{3}{*}{$\begin{array}{l}\text { Journal of Literacy and Tech- } \\
\text { nology Intelligence. }\end{array}$} & \multirow{2}{*}{$\begin{array}{l}\text { M. Gea, R. Soldado, V. Gámiz } \\
\text { (2011). }\end{array}$} \\
\hline & & & \\
\hline & & & G. Fauville et al (2018). \\
\hline
\end{tabular}


(viene)

\begin{tabular}{|c|c|c|c|}
\hline Keywords & Databases & Journals & $\begin{array}{c}\text { Author and year of } \\
\text { publication }\end{array}$ \\
\hline \multirow[t]{7}{*}{ Crowdsourcing } & Access Engineering & Medical Teacher. & \multirow{2}{*}{$\begin{array}{l}\text { S. Tackett, S. Gaglani, J. Heilman, } \\
\text { A. Azzam (2018). }\end{array}$} \\
\hline & \multirow{2}{*}{$\begin{array}{l}\text { IEEE Xplore, Science- } \\
\text { Direct }\end{array}$} & Procedia Computer Science. & \\
\hline & & PLOS ONE. & M. dos Santos (2017). \\
\hline & Scopus & Leonardo Music Journal. & A. Brown, D. Allison (2014). \\
\hline & \multirow[t]{3}{*}{ Jstor } & Science. & D. Casal (2011). \\
\hline & & \multirow[t]{2}{*}{$\begin{array}{l}\text { Expert Systems with Applica- } \\
\text { tions. }\end{array}$} & $\begin{array}{l}\text { L. Von Ahn, B. Maurer, C. McMillen } \\
\text { D. Abraham, M. Blum (2013). }\end{array}$ \\
\hline & & & Y. Yu, J. Kim, K. Shin, G. Jo (2009). \\
\hline
\end{tabular}

Source: own work

S2: Subsequently, complementary searches are aimed at establishing how the definition of tasks and their division can be given for the particular case of the Employability Observatory. In the first instance, information is collected about organizations capable of performing efficiently in complex environments (HRO). In the second instance, information is collected about observatories of different dynamics, mainly identifying tasks and activities.

S3 and S4: Based on the results of S1, the analysis of the obtained information is developed through the critical study of the most important characteristics and features of the $\mathrm{Cl}$ (self-organization, robustness and flexibility).

Open coding: Concepts relevant to the case study are identified based on questions such as: What does it do and how does it work? What are the necessary conditions for the $\mathrm{Cl}$ ?, What characteristics do the actors exhibit?. Table 3 exemplifies the treatment of each consulted model.

Table 3. Cl-based models

\begin{tabular}{|c|c|c|c|}
\hline Title & $\begin{array}{l}\text { What does it do and } \\
\text { how does it work? }\end{array}$ & $\begin{array}{l}\text { Necessary conditions } \\
\text { (Preconditions) }\end{array}$ & $\begin{array}{l}\text { Characteristics } \\
\text { of the Actors }\end{array}$ \\
\hline \multirow{3}{*}{$\begin{array}{l}\text { Using the collective inte- } \\
\text { lligence for inventive pro- } \\
\text { blem solving: A computer } \\
\text { Aided Innovation [22] }\end{array}$} & \multirow{3}{*}{$\begin{array}{l}\text { An agent proposes and } \\
\text { shares a project through } \\
\text { a platform with the other } \\
\text { registered users. The } \\
\text { system provides a list of } \\
\text { possible collaborators. } \\
\text { Through asynchronous } \\
\text { collaboration, a collective } \\
\text { solution is generated. }\end{array}$} & $\begin{array}{l}\text { Asynchronous digital } \\
\text { collaboration platform. }\end{array}$ & \multirow{3}{*}{$\begin{array}{l}\text { Participants with knowle- } \\
\text { dge in different areas of } \\
\text { interest. }\end{array}$} \\
\hline & & $\begin{array}{l}\text { Common language to fa- } \\
\text { cilitate user participation. }\end{array}$ & \\
\hline & & $\begin{array}{l}\text { List of possible collabo- } \\
\text { rators according to their } \\
\text { affinity with the theme of } \\
\text { the project. }\end{array}$ & \\
\hline
\end{tabular}


(viene)

\begin{tabular}{|c|c|c|c|}
\hline Title & $\begin{array}{l}\text { What does it do and } \\
\text { how does it work? }\end{array}$ & $\begin{array}{c}\text { Necessary conditions } \\
\text { (Preconditions) }\end{array}$ & $\begin{array}{c}\text { Characteristics of the } \\
\text { Actors }\end{array}$ \\
\hline \multirow{2}{*}{$\begin{array}{l}\text { Collective Intelligence } \\
\text { Meets Medical Deci- } \\
\text { sion-Making: The Collec- } \\
\text { tive Outperforms the Best } \\
\text { Radiologist [23] }\end{array}$} & \multirow[b]{2}{*}{$\begin{array}{l}\text { A diagnosis (good / bad) } \\
\text { is issued applying Cl rules, } \\
\text { which may include: the } \\
\text { vote of each specialist, } \\
\text { the average rate of true } \\
\text { and false positives, or the } \\
\text { individual accuracy of } \\
\text { each radiologist. }\end{array}$} & Mammography database. & \multirow{2}{*}{$\begin{array}{l}\text { Specialized participants a } \\
\text { specific area of interest. }\end{array}$} \\
\hline & & Participant radiologists. & \\
\hline \multirow{3}{*}{$\begin{array}{l}\text { reCAPTCHA: Human-Ba- } \\
\text { sed Character Recog- } \\
\text { nition via Web Security } \\
\text { Measures [24] }\end{array}$} & \multirow{3}{*}{$\begin{array}{l}\text { Digitization of old printed } \\
\text { material. The contribution } \\
\text { of users who solve a hood } \\
\text { is channeled verifying } \\
\text { that they are human, to } \\
\text { digitize and validate a } \\
\text { word that an optical re- } \\
\text { cognition system cannot } \\
\text { understand. }\end{array}$} & $\begin{array}{l}\text { Digital platforms that use } \\
\text { hood. }\end{array}$ & \multirow{3}{*}{$\begin{array}{l}\text { Participants with basic } \\
\text { knowledge in literacy and } \\
\text { Internet use. }\end{array}$} \\
\hline & & $\begin{array}{l}\text { Database in which the } \\
\text { responses obtained are } \\
\text { stored and validated. }\end{array}$ & \\
\hline & & Internet users. & \\
\hline
\end{tabular}

Source: own work

Axial coding: Table 4 shows the general scheme of axial coding for $\mathrm{Cl}$-based models.

Table 4. General scheme of axial coding

\begin{tabular}{cl}
\hline Phenomenon & \multicolumn{1}{c}{ Cl emergency. } \\
\hline Causal conditions & Preconditions for a Cl: Actors, Knowledge and TIC. \\
\hline Context & HSS. \\
\hline Intervening conditions & Interaction between actors / individual participation. \\
\hline Strategies & Variation in the composition of actors the type and quantity. \\
\hline Consequences & Change of focus in a Cl. \\
\hline
\end{tabular}

Source: own work

Selective coding: The concept "Level" is proposed to refer to a particular configuration of $\mathrm{Cl}$, defined by the composition of the group of actors in variables such as the degree of specialty, diversity and quantity. Cl models at a certain level generally have a particular focus. The above is illustrated in Figure 2. 
Level 1:

Decision making

Level 2:

Generation of several alternatives

Level 3:

Large amount of contributions
High

Medium

Low

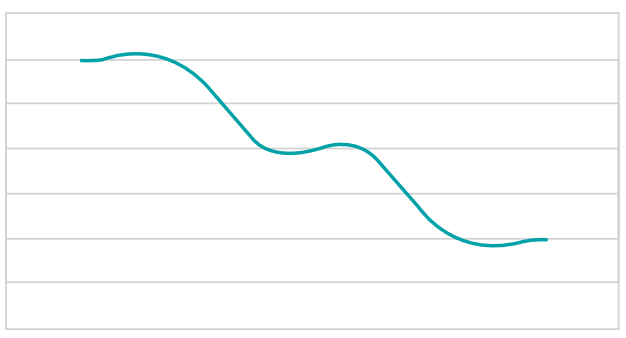

High

Medium

Low

High

Medium

Low
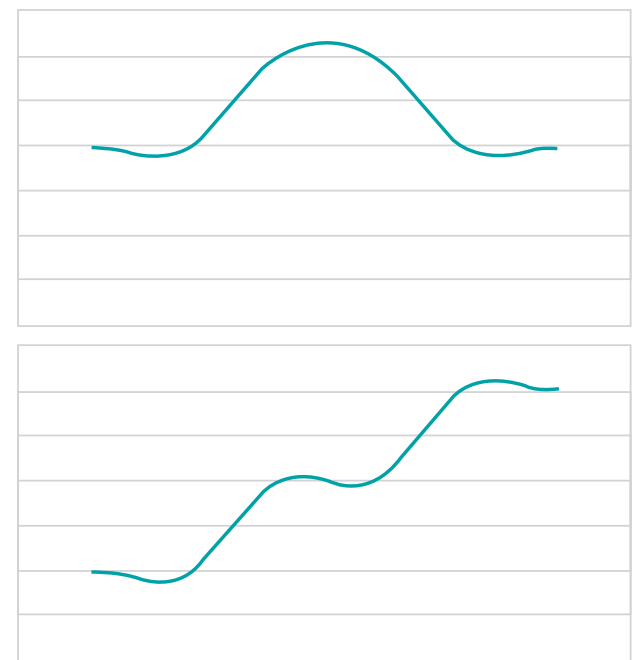

Specialization Diversity Quantity

Figure 2. Overall grade exhibited by $\mathrm{Cl}$ models, depending on their approach Source: own work

S5 and S6: Finally, these stages include the theoretical modeling of the proposal, based on the previous stages.

\subsection{Literature review}

A systematic review of scientific articles is carried out as a technique of exploration and analysis of information. In the first instance the search focused on the term "Collective Intelligence". Highlighting authors such as: Levy, Atlee and Pór, Malone and Bonabeau. Through Google Scholar and databases such as: Access Engineering, IEEE Xplore, ScienceDirect, Scopus, the first relevant or most cited articles in this area were found. Some of the journals found in this review were: Centro Nacional de Información de Ciencias Médicas (INFOMED), Technological Forecasting and Social Change, Journal of Business Research, Leadership Quarterly, among others.

An investigation of models based on $\mathrm{Cl}$ was made, however, non-related content was found according to the need of search. According to this, using an alternative 
strategy with terms and phrases such as "Using Collective Intelligence", or "Collective Intelligence" and through secondary sources such as [18] and [25], it was possible to find the necessary references to locate the sources of early models or applications of $\mathrm{Cl}$ in human social systems (HSS) and words related to the topic such as "Crowdsourcing" or "Collective Intelligence and Crowdsourcing". This gave rise to some examples of the use of $\mathrm{Cl}$ in specific areas such as: medical cases, the web or the Internet (reCAPTCHA, Wikipedia, Google, linux), specialized digital platforms (DuoLingo, m-learning , eHealth, iPixel, Galen and DDtrac), applications (mashup) and some ways of using $\mathrm{Cl}$ to solve social, environmental or educational problems.

22 models of $\mathrm{Cl}$ in articles published in the year 2008 were collected, using the following selection criterion for the articles: the clarity and $\mathrm{Cl}$ management in the study case, the journal or database used and the year of publication. In this search, specialized search engines were used such as: Google academic and institutional databases such as the library system of the Universidad Distrital F.J.C., the Universidad de los Andes, and the Universidad Militar Nueva Granada. The most important journals used were: MIT Sloan Management Review, Cultura y Educacion, Expert Systems with Applications, Journal of Intelligent and Fuzzy Systems, Royal Society Open Science, among others.

\subsubsection{Collective Intelligence}

Pór [26] makes an analogy of a $\mathrm{Cl}$ with a nervous system that coordinates actions and learns from its own experience. Levy explains $\mathrm{Cl}$ as: "A distributed intelligence everywhere, constantly valued, coordinated in real time, which leads to an effective mobilization of competences" [21, p.7]. Atlee \& Pór [28] argue that a Cl will be even more evolved to the extent that it may successfully deal with greater complexity. Malone exposes the $\mathrm{Cl}$ as: "groups of individuals who do things collectively that seem smart" [23, p.1]. Bonabeau [30] affirms that the technological developments enable you to take advantage of the power of the group to expand the traditional group of work and achieve a state of balance between diversity and expertise. Glenn [31] points out that the $\mathrm{Cl}$ arises from the constant interaction between people, information and technology.

Malone et al. [18] expose how the $\mathrm{Cl}$ has been successfully applied to different purposes, such as decision-making processes, solutions research, collection of contributions or links and utilization of resources available in the environment (information, materials, capital, etc.). 
In collective decision-making, some research propose how to take into account the ability of individual members of a group, increasing the accuracy and quality of the decisions [23] [32]. Some models of $\mathrm{Cl}$ raised platforms of interconnection for specialists in health sciences, oriented to generate and share diagnoses, clinical decision-making, recommendation of other specialists and the creation and intelligent management of medical knowledge bases [33] [34] [35] [36] [37].

More accessible models propose digital platforms, that manage information and connect to individuals at any time and place, which are not necessarily experts on a specific topic. Its purpose is usually to take advantage of diversity to generate structured discussions, looking for ideas, alternatives, solutions and creating projects to split large problems in smaller, more manageable problems [22] [32] [38] [39] [40] [41] [42].

Some others recognize the need to continually educate a population to identify barriers [43] [44], Or to improve the quality of the contributions received, where the interaction also promotes a knowledge construction in a collaborative manner, for example: Education and generating ideas for energy conservation [45], The effort of users who learn languages on the internet in order to translate the Web [46], Or the improvement of the quality of articles of health topics in Wikipedia, to incorporate your edition as a methodology of higher education [47].

There are also models with a simpler approach, oriented to the collection and use of large amounts of individual contributions, for the generation of value [24] [48] [49] [50].

\subsection{High Reliability Organizations}

High reliability organizations are those which exist in such dangerous environments where the consequences of mistakes are high, but the occurrence of these is extremely low [51]. They are distinguished by features such as hyper, understood as the extreme diversity of components, systems and levels; a large number of decision-makers in complex communication networks, characterized by the redundancy in the control systems and information; degrees of responsibility, which do not exist in most organizations; the high frequency of immediate feedback on decisions, among other aspects [52].

The structure of the reliable organizations is characterized by having clearly defined roles that may be occupied by different members of the organization, according to the circumstances of the environment. Nogara [19] points to the case of a volunteer firefighting department, under a method of management, incident management, 
hereinafter referred to as the Incident Command System (ICS), where a series of roles called C-FLOP (command, finance, logistics, operations and planning) are borne by any qualified member depending on the situation. That is, the roles are semi-to be set, but not assigned to a particular person, and can be developed by any of them.

The model of operation of these organizations is characterized, among other things, by the permanent creation of emergency situations, constant processes of training, which may be interdisciplinary and that encourage the transfer of knowledge [53]. The interaction is very important as it allows the knowledge of the powers and limitations of individual and collective action among all members of the team [19]. Jobidon, Labrecque, Turcotte, Rousseau, \& Tremblay [54] argue that, although the computers that do not have formal assignment of roles are more flexible, teams with defined roles and functions are able to adapt effectively and more quickly to unexpected events.

\subsection{Observatories}

An observatory is a form of organization that analyzes and provides follow-up to a phenomenon of interest, in order to know the state and evolution of a problem [4] [55]. The observatories can assume functions such as: collection, classification, codification, categorization and creation of databases. They also perform analysis, diagnosis, systematization, standardization, formulation of scenarios or advance as a function of their prospective. Other duties include scientific dissemination, networking, formulation, adaptation and/or development of policies, among others. [56] [57] [58] [59].

Angulo [17] Notes that many of the functions of the observatories refer to the conversion of data and information into useful knowledge. It also presents to the observatories a framework of knowledge management and identifies key roles, providing access in a timely manner to the knowledge available. The National Institute of Public Administration A.C. [56] warns of the impossibility in the operation of the observatories without new information and communication technologies or (TIC).

\section{RESULTS}

For the observatory of employability of the PA, a proposal for a structure based on reliable organizations with semi-formal roles is modeled, coordinated through mechanisms of $\mathrm{Cl}$, developed from the review of models of $\mathrm{Cl}$. Internally the observatory was formed by members of higher education institutions linked to the project: researchers, teachers, graduates and students; externally aiming to link to state organizations, private companies and society in general. It raises and argues for a knowledge manager 
(KM) that not only ensures the reliable and timely access to the knowledge available, but allows for the connection between any agent in the system.

\subsection{Modeling}

Table 5 adapts the concept of $\mathrm{Cl}$ level, to the context of the observatory, identifying at what level the actors involved could operate according to the degree of specialization, the diversity of the group and the amount of individual contributions and exemplifying what type of contribution could be exploited by the Observatory. The management of the observatory would then operate at level 1, while levels 2 and 3 would create links with the environment, in order to take advantage of its resources.

Table 5. Characterization of the levels of $\mathrm{Cl}$

\begin{tabular}{|c|c|c|c|}
\hline Level & Characteristics & Actors & Resources \\
\hline \multirow[t]{6}{*}{1} & High degree of specialization. & \multirow{6}{*}{$\begin{array}{l}\text { Officials of the obser- } \\
\text { vatory: researchers, } \\
\text { teachers, students. }\end{array}$} & Specialized inputs: \\
\hline & Small and homogeneous groups. & & \multirow{5}{*}{$\begin{array}{l}\text { Research and/or } \\
\text { generation of projects } \\
\text { of any kind. }\end{array}$} \\
\hline & There are decision-making processes. & & \\
\hline & Creation of networks of specialists. & & \\
\hline & Generation and Validation of knowledge. & & \\
\hline & Creation of knowledge bases. & & \\
\hline \multirow[t]{4}{*}{2} & The average level of competence. & \multirow{4}{*}{$\begin{array}{l}\text { Users linked to the } \\
\text { network: students, } \\
\text { graduates, external orga- } \\
\text { nizations. }\end{array}$} & Various inputs: \\
\hline & High degree of diversity. & & \multirow{3}{*}{$\begin{array}{l}\text { Personal data, labor } \\
\text { offers, ideas, options, } \\
\text { approaches, among } \\
\text { others. }\end{array}$} \\
\hline & Creation of open networks. & & \\
\hline & $\begin{array}{l}\text { Interaction and search for a greater variety of } \\
\text { options, through the division of big problems } \\
\text { into smaller ones. }\end{array}$ & & \\
\hline \multirow[t]{3}{*}{3} & Minimum level of competence. & \multirow{3}{*}{$\begin{array}{l}\text { Members of the society in } \\
\text { general. }\end{array}$} & Simple inputs: \\
\hline & Use of the Web. & & Data and others. \\
\hline & $\begin{array}{l}\text { Collection of large volumes of simple inputs, } \\
\text { and independent. }\end{array}$ & & \\
\hline
\end{tabular}

Source: own work

\subsection{Organizational Structure}

As to the division of labor for the actors at level 1, the organizational structure is supported by reliable organizations for its robustness, flexibility and agility. Based on the roles of the ICS, Table 6 proposes similarly semi-formal roles adapted to the context of the observatory. 
Table 6. Roles and activities identified for the model

\begin{tabular}{ll}
\hline \multicolumn{1}{c}{ Internal Role } & \multicolumn{1}{c}{ Activities } \\
\hline Direction (D) & To assess situations and identify the approach must be the same [19], \\
& Given the social, political, economic, etc. \\
& Make decisions [60], [61]. \\
& Be the representative image of the observatory and create strategic allian- \\
& ces [19]. Intervene in the resolution of problems [16]. \\
\hline Sustainability (S) & Identifying sources of funding [4]. \\
& Managing the budget, cost structure and creation of financing plans [19]. \\
\hline Logistics (L) & Organization of events (seminars, meetings, congresses and other related \\
& actions) [55] [22].. \\
& Coordination of training events that require it (courses, workshops, diplo- \\
& mas, etc.) for the articulation of actors. \\
& Keep track in real time [14]. \\
\hline Planning/ strategy (P) & Data collection, analysis and dissemination of information [55]. \\
& Creation of processes of innovation, research and development [17]. \\
& Training and continuous training of the actors [17]. \\
& Creation and management of information systems and platforms [62]. \\
& Creation of indicators and results dissemination [17]. \\
\hline & Development of reports and evaluation techniques [54]. \\
& Strategic alliances [19]. \\
& Planning of training events (workshops, courses, diplomas, etc) and \\
training methods and training to members [55], [19].
\end{tabular}

Source: own work

\subsection{Knowledge Manager}

A common point between the three levels of $\mathrm{Cl}$ raised in Table 5, is that it always includes three elements: actors, technology and knowledge. It is inferred that a $\mathrm{Cl}$ can occur, if and only if they are present. In the review of $\mathrm{Cl}$, the technological element is permanent, either as Web sites, open digital platforms, specialized applications or knowledge bases. The review of observatories concludes that this type of organization depends to a large extent on TIC, to the point of the impossibility of operation in his absence.

A proposal, that integrates all levels of $\mathrm{Cl}$, is that the more the requirement in the handling of information implies an observatory and its technological dependence, the greater the absolute need for a system described by By (1995) in your analogy, which expresses the global capabilities to: interconnect to all its members, collect your 
data and inputs, and facilitate a rapid exchange and processing of information in the absence of a central controller. ${ }^{1}$

The system called Knowledge Manager (KM), in addition to the above, shall among other things: be accessible and geared towards simplicity of interactions [45]; Ensure reliable and timely access to available knowledge [17]; Have constantly updated knowledge about powers, limitations and evolution of the actors of level 1, in order to generate recommendations regarding the role that can assumed, in addition to constantly promoting and enabling training processes [17] [19].

For the exploitation of resources, the system should collect data, information and contributions of actors in levels 2 and 3 . It is crucial to the elimination of language barriers in raising platforms that are in line with the abilities of the social group [45]. The system will also be able to take advantage of other platforms of greater use such as social networks or debate forums for data acquisition, dissemination of results or promotion of non-formal learning [39] in order to generate a greater social impact.

\subsection{Coordination Mechanisms}

Making use of interconnected platforms according to the skills of the members, in a manner similar to social networks, each actor must build a profile. This is fed with personal data, skills, areas of interest, academic and labor resupplied with experience, results, participation within the observatory, among others.

It is intended to present relevant information in a personalized way. The members must be able to gain access at any time and place to: your profile and trajectory in the observatory; the state and evolution a particular project; custom suggestions about discussions, events, online training and other content of interest in a simple and attractive manner.

The platforms will be linked to the KM in a manner that makes it possible to provide actors of level 1 real-time access to accurate and relevant information to enable them to decide quickly and in an organized manner. An actor of level 1 with relevant information in a framework for action and time will be able to: assume a role in the organization, be trained in areas of interest, be linked to a project or propose their own, share it and get a list of potential partners, open it to the public, structure discussions, as well as disseminate results, needs, future lines of work, educational content or content of general interest.

Similar to the ICS, the observatory can have different approaches in time. At a given point in your approach, you may be oriented towards the search for economic

1 The nervous system of an organization. 
resources and in another, towards the dissemination of results, depending on your goals, emergencies, and the conditions of the environment that need to be faced. Table 7 proposes activities and criteria by which actors could be organized, thanks to the technological support of the KM in providing relevant and timely information.

Table 7. Activities and coordination criteria identified for the model

\begin{tabular}{|c|c|c|}
\hline Activity & Criteria & Description \\
\hline Selecting Roles & $\begin{array}{l}\text { Need. } \\
\text { Competencies. }\end{array}$ & $\begin{array}{l}\text { Given an approach, based on the competences of } \\
\text { the actors, the KM makes suggestions tailored to } \\
\text { each about what roles could be assumed. }\end{array}$ \\
\hline Training Continues & $\begin{array}{l}\text { Need. } \\
\text { Competencies. }\end{array}$ & $\begin{array}{l}\text { Given an approach, based on the competences of } \\
\text { the actors, the KM makes suggestions tailored to } \\
\text { each one of those who should be trained. }\end{array}$ \\
\hline Generation of projects & $\begin{array}{l}\text { Need. } \\
\text { Impact. }\end{array}$ & $\begin{array}{l}\text { Once arisen, they are approved and managed with } \\
\text { support in the KM according to the situation or } \\
\text { focus of the observatory. }\end{array}$ \\
\hline $\begin{array}{l}\text { Selection and invitation of } \\
\text { contributors to a project }\end{array}$ & $\begin{array}{l}\text { Proximity to the project. } \\
\text { Competition. } \\
\text { Participation }\end{array}$ & $\begin{array}{l}\text { The KM generates suggestions of collaborators for a } \\
\text { specific project from the relevance that have criteria } \\
\text { such as: the proximity of the project, the degree of } \\
\text { competition and the history of the participation of } \\
\text { actors. }\end{array}$ \\
\hline Dissemination of results & $\begin{array}{l}\text { Scope. } \\
\text { Powers of the public. }\end{array}$ & $\begin{array}{l}\text { Based on the scope of a project, and the skills of } \\
\text { the target audience, the KM gives suggestions of } \\
\text { how and where the results should be presented. }\end{array}$ \\
\hline
\end{tabular}

Source: own work

In collective decision-making it is important to take into account the individual capacity of each member in a particular situation, recognizing that all actors are not equally valuable in all situations. Given the theoretical modeling developed so far, the decision-making is presented as a process that consists of the identification of needs, the generation of alternatives and the selection of one or more depending on the case. To illustrate it, a voting system, based on weighted averages where every participant has a weight defined by their ability to provide decision making actions in a situation is proposed; setting out criteria for assessing the ability of an individual to respond, i.e. the weight of each actor in the vote.

Firstly, depending on the approach or particular needs of the situation, the actors involved assign a relative weight to each criterion (WCi), where the sum of these is equal to one. Secondly, the KM, based on information in the personal profile of each actor in the group, will generate a relative score $(\mathrm{Pi})$ in a range from zero to one for each criterion. The weight $(\mathrm{W})$ of each actor in a collective decision-making process is the sum of the relative weight of the $i^{\text {th }}$ criteria by which the relative score of that criterion is calculated, as expressed in (1): 


$$
W=\sum_{i=1}^{n}\left(W C_{i} \times P_{i}\right)
$$

In a simple process, each member selects an alternative and chooses the one that has greater average weight. Table 8 proposes basic criteria for an example where the problem to be addressed is the educational needs in Colombia.

Table 8. Criteria for assessment of actors in a particular situation, identified for the model

\begin{tabular}{lll}
\hline & \multicolumn{1}{c}{ Criteria } & \multicolumn{1}{c}{ Description } \\
\hline Relative Weight & $\begin{array}{ll}\text { Proximity to the project }=0.4 \\
\text { Competition }=0.5\end{array}$ & $\begin{array}{l}\text { The context of the problem makes } \\
\text { criteria such as proximity and } \\
\text { level of competence to be of more } \\
\text { relevance than participation. }\end{array}$ \\
\hline $\begin{array}{l}\text { Actor Score: } \\
\text { Director of the observatory }\end{array}$ & Proximity to the project $=1.0$ & $\begin{array}{l}\text { For each criterion, the score is } \\
\text { calculated on the basis of the infor- } \\
\text { mation of all members of the group } \\
\text { that makes the decision. }\end{array}$ \\
\hline
\end{tabular}

Source: own work

In the previous case, a sum-product is finally made between the criteria of the relative weight (depending on the situation) and the actor's score in this situation, granting a weight of 0.93 to the actor to make a decision. This score will be averaged with the weights and decisions of the other participating actors.

\section{DISCUSSION AND CONCLUSIONS}

The success of this research lies in the creation of an organizational structure and coordination that overcomes the limitations of the traditional paradigm. In this model, the actors involved in a framework of $\mathrm{Cl}$ (levels of $\mathrm{Cl}$ ) that sets the type of linkage and/ or participation in the observatory are defined. On the other hand, the basic roles that describe and group the functions and/or basic processes necessary for the operation of the Organization in its context have been established. The role and functions of the KM as an element active articulator of the highest importance has also been defined. Finally, mechanisms for coordination, for which it is essential that each actor has access to relevant information in a timely manner, have been established. 
Based on the above, the observatory has features such as agility, robustness and adaptation necessary for its functionality and sustainability over time. To date, the modeling presented here is based on grounded theory, however, validation of the same is still under development by means of an agent-based simulation and is expected to present the results of their performance and effectiveness shortly.

\section{REFERENCES}

[1] UDFJC - Sistema Integrado de Comunicaciones, Países de la Alianza del Pacífico crearán Observatorio Regional Laboral de Empleabilidad | Universidad Distrital Francisco José de Caldas, 2018. [Online]. Available: https:/www.udistrital.edu.co/paises-alianza-del-pacifico-crearan-observatorio-regional-laboral-empleabilidad. [Accessed: 23-Oct-2018].

[2] H. Mintzberg, Mintzberg y la dirección, 1st ed. 1991. [Online]. Available: https://books. google.com.co/books?id=CZX1NRqyPkMC\&printsec=frontcover\&dq=H.+Mintzberg, ${ }^{+-}$ Mintzberg+y+la+direcci\%C3\%B3n,+1st+ed.+1991.\&hl=es\&sa=X\&ved=0ahUKEwiinKmFutLIAhWFrVkKHbPnCB8Q6AEIKDAA\#v=onepage\&q\&f=false

[3] L. Bohórquez, D. Moreno, and E. Espitia, Diseño de estructuras organizacionales como redes complejas: Una propuesta de estudio, p. 21, 2015.

[4] R. Silva, “Qué es un observatorio? Apuntes para la discusión," Vínculos, vol. 1, pp. 189-212, 2013. [Online]. Available: http://www.publicaciones.cucsh.udg.mx/pperiod/vinculos/pdfs/ vinculos4/V4_11

[5] F. E. Kast and J. E. Rosenzweig, Administración en las organizaciones: enfoque de sistemas y de contingencias, 4th ed. 1987.

[6] J. M. Ivancevich, R. Konopaske, y M. Matteson, Comportamiento organizacional, 7th ed. 2012. [Online]. Available: https://es.scribd.com/document/251460464/Comportamiento-Organizacional-7ed-Ivancevich-Konopaske-y-Matteson

[7] F. Mochón and M. Mochón, Maria del Carmen Sáez, Administración - Enfoque por competencias con casos latinoamericanos, 1st ed. 2014.

[8] R. L. Daft, Teoría y diseño organizacional, 10th ed. 2015. [Online]. Available: https://cucjonline. com/biblioteca/files/original/a470398d881ef04626b994461fc4879b.pdf

[9] E. B. Franklin, E. Benjamín, and F. Fincowsky, Organización de empresas: Análisis, diseño y estructura, 1st ed. 1999. 
[10] A. H. Van De Ven, A. L. Delbecq, and R. Koenig, "Determinants of Coordination Modes within Organizations," Am. Sociol. Rev., vol. 41, no. 2, p. 322, Apr. 1976.

[11] T. A. Petit, Fundamentos de coordinación administrativa: para supervisores, jefes de departamento y ejecutivos, 1st ed., 1978.

[12] G.Huerta,yJ.Rodríguez,Desarrollodehabilidadesdirectivas, 1sted.,2006.[Online].Available:https://es.scribd.com/doc/256421718/Desarrollo-de-Habilidades-Directivas-huerta-Rodriguez

[13] T.W. Malone and K. Crowston, "The interdisciplinarystudy of coordination," ACM Comput. Surv., vol. 26, no. 1, pp. 87-119, Mar. 1994. [Online]. doi: http://dx.doi.org/10.1145/174666.174668

[14] Y. Castillo, N. Gómez, and L. Bohórquez, "Rasgos estructuras para el manejo de crisis en sistemas sociales humanos," 2018.

[15] L. Bohórquez, "La Comprensión de las Organizaciones Empresariales y su Ambiente como Sistemas de Complejidad Creciente: Rasgos e Implicaciones," 2016. [Online]. doi: http://dx. doi.org/10.14483/udistrital.jour.reving.2016.3.a07

[16] D. Watts, "Seis grados de separación," La ciencias de las redes. 2006. [Online]. Available: https://books.google.com.co/books?id=jt4ktVJ427QC\&print-sec=frontcover\&hl=es\&source=gbs_ge_summa-ry_r\&cad=0\#v=onepage\&q\&f=false

[17] N. Angulo, “Qué son los observatorios y cuales son sus funciones?," Innovación Educ., vol. 9, p. 47, 2009. [Online]. Available: http://www.redalyc.org/articulo.oa?id=179414895002

[18] T. W. Malone, R. Laubacher, and C. Dellarocas, "The collective intelligence genome," IEEE Eng. Manag. Rev., vol. 38, no. 3, pp. 38-52, 2010. [Online]. Available: http://gaius.cbpp.uaa.alaska. edu/afef/Collectivelntel.pdf

[19] C. Nogara, "Effective Utilization of the Incident Command System in a High-Reliability Environment," no. June 2014, pp. 146-154, 2003.

[20] A. Strauss and J. Corbin, Bases de la investigación cualitativa: técnicas y procedimientos para desarrollar la teoría fundamentada [Bases of qualitative research: techniques and procedures for developing grounded theory]. p. 341. Medellín: Editorial Universidad de Antioquia. 2002.

[21] R. Hernandez, C. Fernandez, and M. del P. Babtista, Metodología de la Investigación, Sexta edic. México, 2014. 
[22] R. Lopez, J. Pierre, J. Marc, and S. Negny, "Using the Collective Intelligence for inventive problem solving: A contribution for Open Computer Aided Innovation," Expert Syst. Appl., vol. 42, no. 23, pp. 9340-9352, Dec. 2015. [Online]. doi: https://doi.org/10.1016/j.eswa.2015.08.024

[23] M. Wolf, J. Krause, P. A. Carney, A. Bogart, and R. H. J. M. Kurvers, "Collective Intelligence Meets Medical Decision-Making: The Collective Outperforms the Best Radiologist," PLoS One, vol. 10, no. 8, p. e0134269, Aug. 2015. [Online]. doi: https://doi.org/10.1371/journal.pone.0134269

[24] L. Von, B. Maurer, C. McMillen, D. Abraham, and M. Blum, "reCAPTCHA: Human-Based Character Recognition via Web Security Measures," Science (80-. )., vol. 321, no. 5895, pp. 1465-1468, Sep. 2008. [Online]. doi: https://doi.org/10.1126/science.1160379

[25] D. Rincón, J. Valdes, and L. Bohórquez, "Collective Intelligence for Decision-Making in Complex Environments: Literature Review," in IFIP Advances in Information and Communication Technology, vol. 519, 2018, pp. 471-480. [Online]. doi: https://doi. org/10.1007/978-3-319-92007-8_40

[26] G. Pór, Questing for Collective Intelligence. In community Building in Organizations: Renewing Spirit and Learning in Business, 1st ed. New Leaders Press, 1995.

[27] P. Lévy, Inteligencia colectiva: por una antropología del ciberespacio. Washington, DC.: Centro Nacional de Informcación de Ciencias Médicas (INFOMED), 1997. [Online]. Available: http:// inteligenciacolectiva.bvsalud.org/public/documents/pdf/es/inteligenciaColectiva.pdf

[28] T. Atlee and G. Pór, Collective Intelligence as a Field of Multi-disciplinary Study and Practice. 2000.

[29] T. W. Malone, What is collective intelligence and what will we do about it?. Collective intelligence: creating a prosperous world at peace, 1st ed. 2008.

[30] E. Bonabeau, "Decisions 2. 0: The Power of Collective Intelligence," MIT SLOAN Manag. Rev., vol. 50, no. 50211, 2009. [Online]. Available: https://pdfs.semanticscholar.org/457c/ e5693ac317c7230d6c024a18777d110a93fa.pdf

[31] J. C. Glenn, "Collective intelligence systems and an application by The Millennium Project for the Egyptian Academy of Scientific Research and Technology," Technol. Forecast. Soc. Change, vol. 97, pp. 7-14, Aug. 2015.

[32] R. H. J. M. Kurvers, M. Wolf, M. Naguib, and J. Krause, "Self-organized flexible leadership promotes collective intelligence in human groups," R. Soc. Open Sci., vol. 2, no. 12, p. 150222, Dec. 2015. [Online]. doi: http://dx.doi.org/10.1098/rsos.150222 
[33] A. Camacho, M. G. Merayo, and M. Núñez, "Collective intelligence and databases in eHealth: A survey1," J. Intell. Fuzzy Syst., vol. 32, no. 2, pp. 1485-1496, Jan. 2017. [Online]. Available: https://pdfs.semanticscholar.org/447a/6a487078356123418a7c4bdda419f9865d68.pdf

[34] G. Hernández, A. Rodríguez, G. Alor, J. M. Gómez, M. A. Mayer, and R. Posada, "Knowledge Acquisition for Medical Diagnosis Using Collective Intelligence," J. Med. Syst., vol. 36, no. S1, pp. 5-9, Nov. 2012. [Online]. doi: https://doi.org/10.1007/s10916-012-9886-3

[35] G. S. Hernández, E. E. Ceh, J. L. Sanchez, M. Villanueva, A. Rodríguez, and Y. Pérez, "Collective intelligence in medical diagnosis systems: A case study," Comput. Biol. Med., vol. 74, pp. 45-53, Jul. 2016. [Online]. doi: https://doi.org/10.1016/j.compbiomed.2016.04.016

[36] Y. Pérez, G. Alor, G. Cortes, and A. Rodríguez, "Collective intelligence as mechanism of medical diagnosis: The iPixel approach,” Expert Syst. Appl., vol. 40, no. 7, pp. 2726-2737, 2013. [Online]. doi: http://dx.doi.org/10.1016 / j.eswa.2012.11.020

[37] A. Tacchella et al., "Collaboration between a human group and artificial intelligence can improve prediction of multiple sclerosis course: a proof-of-principle study," F1000Research, vol. 6, no. 0, p. 2172, Dec. 2017. [Online]. doi: http://dx.doi.org/10.12688/f1000research.13114.1

[38] S. Chaudoin, J. Shapiro, and D. Tingley, Revolutionizing Teaching and Research with a Structured Debate Platform, p. 12, 2017. [Online]. Available: https://scholar.princeton.edu/ sites/default/files/jns/files/structureddebate.pdf

[39] M. Gea, R. M. Soldado, and V. Gámiz, "Collective intelligence and online learning communities," Int. Conf. Inf. Soc. (i-Society 2011), pp. 319-323, 2011.

[40] M. Mačiulienè and A. Skaržauskienè, "Emergence of collective intelligence in online communities," J. Bus. Res., vol. 69, no. 5, pp. 1718-1724, May 2016. [Online]. doi: https://doi.org/10.1016/j.jbusres.2015.10.044

[41] M. M. L. dos Santos, "Holism, collective intelligence, climate change and sustainable cities," Procedia Comput. Sci., vol. 109, pp. 763-770, 2017. [Online]. doi: https://doi.org/10.5383/ ijtee.15.02.009

[42] A.W. Brown and D. B. Allison, "Using Crowdsourcing to Evaluate Published Scientific Literature: Methods and Example," PLoS One, vol. 9, no. 7, p. e100647, Jul. 2014. [Online]. doi: https://doi. org/10.1371/journal.pone.0100647 
[43] G. Fauville et al., "Using collective intelligence to identify barriers to teaching 12-19 year olds about the ocean in Europe," Mar. Policy, vol. 91, no. October 2017, pp. 85-96, May 2018. [Online]. doi: https://doi.org/10.1016/j.marpol.2018.01.034

[44] D. Gregg, "Developing a collective intelligence application for special education," Decis. Support Syst., vol. 47, no. 4, pp. 455-465, Nov. 2009. [Online]. doi: https://doi.org/10.1016/ j.dss.2009.04.012

[45] L. S. G. Piccolo, A. De Liddo, G. Burel, M. Fernandez, and H. Alani, "Collective intelligence for promoting changes in behaviour: a case study on energy conservation," Al Soc., vol. 33, no. 1, pp. 15-25, Feb. 2018. [Online]. doi: https://doi.org/10.1007/s00146-017-0710-y

[46] L. von Ahn, "Augmented intelligence: the Web and human intelligence," Philos. Trans. R. Soc. A Math. Phys. Eng. Sci., vol. 371, no. 1987, pp. 20120383-20120383, Feb. 2013. [Online]. doi: https://doi.org/10.1098/rsta.2012.0383

[47] S. Tackett, S. Gaglani, J. Heilman, and A. Azzam, "The reCAPTCHA of medical education," Med. Teach., vol. 0, no. 0, pp. 1-3, Apr. 2018.

[48] D. P. Casal, "Crowdsourcing the Corpus: Using Collective Intelligence as a Method for Composition," Leonardo Music J., vol. 21, no. 21, pp. 25-28, Dec. 2011. [Online]. doi: https:// doi.org/10.1162/LMJ_a_00057

[49] M. Avlonitis, I. Karydis, and S. Sioutas, "Early prediction in collective intelligence on video users' activity," Inf. Sci. (Ny)., vol. 298, pp. 315-329, 2015. [Online]. doi: http://dx.doi.org/10.1016/j.ins.2014.11.039

[50] Y. H. Yu, J. H. Kim, K. Shin, and G. S. Jo, "Recommendation system using location-based ontology on wireless internet: An example of collective intelligence by using 'mashup' applications," Expert Syst. Appl., vol. 36, no. 9, pp. 11675-11681, 2009. [Online]. doi: https://doi. org/10.1016/j.eswa.2009.03.017

[51] D. P. Baker, R. Day, and E. Salas, "Teamwork as an essential component of high-reliability organizations.," Health Serv. Res., vol. 41, no. 4, pp. 1576-98, Aug. 2006. [Online]. doi: http:// dx.doi.org/10.1111/ j.1475-6773.2006.00566.x

[52] K. H. Roberts and D. M. Rousseau, "Research in nearly failure-free, high-reliability organizations: having the bubble," IEEE Trans. Eng. Manag., vol. 36, no. 2, pp. 132-139, May 1989. [Online]. doi: http://dx.doi.org/10.1109/17.18830 
[53] A. S. Hwang, "Training strategies in the management of knowledge," Journal of Knowledge Management. 2003. [Online]. doi: https://doi.org/10.1108/13673270310485659

[54] M.-E. Jobidon, A. Labrecque, I. Turcotte, V. Rousseau, and S. Tremblay, "Adaptability in Crisis Management: The Role of Organizational Structure," 18th Int. Command Control Res. Technol. Symp., vol. 4, pp. 1-19, 2013. [Online]. Available: https://apps.dtic.mil/dtic/tr/fulltext/u2/ a587021.pdf

[55] M. Á. Sagastizabal, "La diversidad sociocultural en la educación: creación de un Observatorio en la provincia de Santa Fe (Argentina)," Cult. y Educ., vol. 11, no. 2-3, pp. 211-216, 1999. [Online]. doi: https://doi.org/10.1174/113564002320516876

[56] Instituto Nacional de Administración Pública A.C., "La función social de los Observatorios. El caso del Observatorio Latinoamericano de la Administración Pública (OLAP)," Ser. Prax., no. 154, p. 48, 2014. [Online]. Available: http://www.inap.mx/portal/images/pdf/book/praxis 154.pdf

[57] O. Fontal, "El Observatorio de Educación Patrimonial en España," Cult. y Educ., vol. 28, no. 1, pp. 254-266, 2016.

[58] B. F. Newman and L. K. Couturier, "Trading Public Good in the Higher Education Market," Obs. borderless High. Educ., no. January, p. 14, 2002. [Online]. Available: https://eu.pravo. hr/_download/repository/Trading_Public_Good_in_the_Higher_Education_Market.pdf

[59] M. Á. Rivera and E. Rubiano, "El observatorio, una herramienta para el sector social, cooperativo y solidario en la región Tolima," Coop. Desarro., vol. 24, no. 109, 2016. [Online]. doi: https:// doi.org/10.16925/co.v24i109.1510

[60] K. A. McHugh, F. J. Yammarino, S. D. Dionne, A. Serban, H. Sayama, and S. Chatterjee, "Collective decision making, leadership, and collective intelligence: Tests with agent-based simulations and a Field study," Leadersh. Q., vol. 27, no. 2, pp. 218-241, 2016. [Online]. doi: https://doi.org/10.1016/j.leaqua.2016.01.001

[61] I. Command and T. Symposium, "Title of Paper: Preparing Capable Decision Makers for an Uncertain Future Within Underdeveloped, Degraded and Denied Operational Environments Topic - Track: Track 2: Approaches and Organizations Name of Author: Russell E . Bryant Decoy Production M," no. 202, 2013. [Online]. Available: https://apps.dtic.mil/dtic/tr/fulltext/ u2/a586822.pdf 
[62] A. J. C. Simoes and C. A. Hidalgo, "The Economic Complexity Observatory: An Analytical Tool for Understanding the Dynamics of Economic Development," Scalable Integr. Anal. Vis. Pap. from 2011 AAAl Work., pp. 39-42, 2011. [Online]. Available: https://www.aaai.org/ocs/index. php/WS/AAAIW11/paper/view/3948/4325 